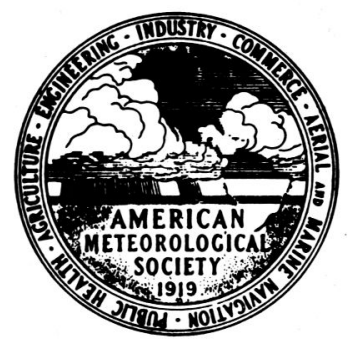

Imerlican Meteopologileal Soctelty

announces

\author{
The Father James B. Macelwane Annual Awards \\ for original papers on meteorology, \\ The Howard T. Orville Scholarship in Meteorology, \\ and
}

The Howard H. Hanks, Jr., Scholarship in Meteorology

\section{Undergraduate awards}

\section{Undergraduate scholarships}

Howard T. Orville Scholarship in

Meteorology

and

Howard H. Hanks, Jr., Scholarship in Meteorology
The Father James B. Macelwane Annual Awards were established by the American Meteorological Society to honor the late Rev. James B. Macelwane, S. J., a world renowned authority on seismology, who was a geophysicist and Dean of the Institute of Technology, Saint Louis University, until his death in 1956. Award stipends are supported by Weather Corporation of America, private meteorological consultants, Saint Louis, Mo. The author of the paper awarded first place by the committee of judges receives a stipend of $\$ 200$, and the author of the second place paper receives $\$ 100$.

The purpose of these awards is to stimulate interest in meteorology among college students through the encouragement of original student papers concerned with some phase of the atmospheric sciences. All registered undergraduates of a college or university in the Americas are eligible to participate. The only restrictions are that the participating student must be enrolled as an undergraduate at the time the paper is written, and no more than two students from any one institution may enter papers in any one contest.

To consider papers for the Macelwane Awards, the committee of judges must receive l) the paper with a letter of application from the author, and 2) a letter from the department head or other faculty member of the major department, confirming that the author was an undergraduate student at the time the paper was written and indicating the elements of the paper that represent original contributions by the student.

The above information must be received at the headquarters of the American Meteorological Society, 45 Beacon Street, Boston, Mass. 02108, during the twelve-month period preceding 15 June of the current year. The judges may further consider papers that were submitted during the prior twelve-month period but that did not receive an award during the previous competition.

The evaluation of papers occurs during the summer. Announcement of the recipients of the awards is made at the following Annual Meeting of the Society.

The Howard T. Orville Scholarship in Meteorology honors the late Howard T. Orville, Head of the Naval Aerological Seryice, 1940-50, whose service was marked by many commendations. After his retirement from the Navy, he held key industrial posts and was Chairman of the Advisory Committee on Weather Control in 1953. Capt. Orville was President of the American Meteorological Society, 1948-49. Through a bequest from the estate of Howard T. Orville and contributions from members of his family, the Society gives an annual scholarship of $\$ 600$.

The Howard H. Hanks, Jr., Scholarship in Meteorology honors the late Howard H. Hanks, Jr., who was Vice-President of Weather Corporation of America when his career was cut short by a plane crash in 1969. A donation by William J. Hartnett, President of Weather Corporation of America, provides funds for the scholarship in the amount of $\$ 400$ per annum.

The Orville and Hanks Scholarships are awarded to students on the basis of their academic excellence and achievement.

The candidates must be entering their final undergraduate year as majors in a meteorology department or other department actively engaged in work on some aspect of atmospheric science. They must intend to make atmospheric science their career and have completed at least 54 semester hours or the equivalent toward a bachelor's degree.

To consider a candidate for a scholarship, the American Meteorological Society must receive l) a letter of application from the candidate, which includes a statement, in fewer than 500 words, of the candidate's future goals and aspirations, and 2) a letter of recommendation from the chairman or other designated faculty member of the major department, reflecting the overall view of the department faculty, accompanied by a list of the candidate's courses and grades in the major subject and in mathematics, physics, and other sciences.

The above information must be received at the headquarters of the American Meteorological Society, 45 Beacon Street, Boston, Mass. 02108, during the twelve-month period preceding 15 June of the calendar year in which the applicant enters the final complete undergraduate year. The evaluation of applications occurs during the summer. Announcement of the recipients of the scholarships is made at the following Annual Meeting of the Society. 